\title{
Kebermaknaan Hidup pada Anak Pidana di Bali
}

\author{
A.A. Sagung Suari Dewi dan David Hizkia Tobing \\ Program StudiPsikologi, Fakultas Kedokteran, UniversitasUdayana \\ sagung_ary@yahoo.co.id
}

\begin{abstract}
Abstrak
Dalam beberapa tahun terakhir, kasus kenakalan remaja di Indonesia semakin meningkat. Kasus terbanyak adalah pelecehan seksual, penyalahgunaan narkoba, pembunuhan, dan pencurian (Hasinta, 2010). Berdasarkan UndangUndang Nomor 12 tahun 1995 yang mengatur tentang pemasyarakatan, bahwa pelaku tindakan-tindakan kenakalan remaja yang berusia 18 tahun atau kurang dari 18 tahun yang terbukti bersalah, akan dibina di dalam lembaga pemasyarakatan khusus anak seperti Lembaga Pemasyarakatan Kelas II B Karangasem, dengan sebutan anak pidana. Terdapat perbedaan dalam pola hidup di dalam sebuah lembaga pemasyarakatan dengan pola hidup di luar lembaga pemasyarakatan, seperti hilangnya perasaaan bebas individu (Dewi, 2012). Anak pidana akan memerlukan suatu tujuan dan cara tertentu untuk mempertahankan hidup dalam situasi tersebut, agar hidup menjadi lebih bermakna. Hal inilah yang menarik peneliti untuk mencari tahu mengenai kebermaknaan hidup anak pidana di Lembaga Pemasyarakatan Anak Kelas II B Karangasem.

Penelitian ini menggunakan metode kualitatif dengan desain fenomenologi. Subjek yang digunakan dalam penelitian ini sebanyak enam orang anak pidana. Hasil penelitian memperlihatkan bahwa terdapat enam aspek kebermaknaan hidup pada anak pidana di Lembaga Pemasyarakatan Anak Kelas II B Karangasem, yaitu kepuasan hidup, hal yang paling berarti dalam hidup, kebebasan, kepantasan hidup, perubahan yang dialami, dan penerimaan terhadap kehidupan di dalam lapas. Hasil penelitian ini akan dibahas dalam konteks intergroup process.
\end{abstract}

Kata kunci : kebermaknaan hidup, remaja, lembaga pemasyarakatan, Bali

\begin{abstract}
In recent years, cases about juvenile deliquency in Indonesia has increased with the most cases are sexual harassment, drugs, murdering, and stealing (Hasinta, 2010). According to Indonesian regulation nomor 12 tahun 1995, if a juvenile deliquency case has been done by an 18 year old adolescent or less and it has been proved by the court, the adolescent will be called anak pidana and they will be educated in a prison for adolescent but more like education centre, such as in Lembaga Pemasyarakatan Anak Kelas II B Karangasem, Bali. Living in a lembaga pemasyarakatan will be much different from common life outside, such as experiencing the loss of freedom (Dewi, 2012). In surviving to this situation, adolescent needs to know the meaning of their life and this issue attracts the researcher to find out what is the meaning of life of anak pidana who lives in Lembaga Pemasyarakatan Anak Kelas II B Karangasem.

This study use qualitative method with phenomenological approach, with 6 anak pidana as the subject. The result shows that there are 6 aspect of the meaning of life of anak pidana who lives in Lembaga Pemasyarakatan Anak Kelas II B Karangasem, which are the most valuable thing in life, satisfaction in life, freedom, right to live, personal change, and life-acceptance in Lembaga Pemasyarakatan Anak Kelas II B Karangasem. Detailed result will be discussed in the context of intergroup process.
\end{abstract}

Keywords: meaning of life, adolescent, prison, Bali 


\section{A. A. S. S. DEWI DAN D. H. TOBING}

\section{LATAR BELAKANG}

Proses perkembangan manusia dimulai dari masa anak-anak, dilanjutkan dengan masa remaja, kemudian masa dewasa. Masa remaja merupakan masa peralihan dari masa anak-anak menuju dewasa, yang diikuti adanya perubahan fisik, kognitif dan sosial emosional (Santrock dalam Henggaryadi, 2009). Selain sebagai masa peralihan, masa remaja juga ditandai dengan pencarian jati diri. Pencarian jati diri remaja sangat dipengaruhi oleh dua faktor dasar, yaitu faktor nature atau fakor genetis, dan nurture seperti faktor lingkungan, budaya, dan pola asuh yang diterapkan orangtua (Chaplin dalam Desmita, 2012).

Terdapat empat pola asuh yang diungkapkan oleh Baumrind (dalam Bradley, 2005). Pola asuh authoritative yang berfokus pada pencapaian kedewasaan dan kontrol diri pada remaja, yang tetap mendapatkan bimbingan dari orang tua, akan meningkatkan pencapaian akademik, regulasi diri yang tinggi pada remaja tersebut, dan rendahnya kemungkinan remaja ini untuk melakukan perilaku beresiko. Orang tua yang menerapkan pola asuh authoritarian akan menuntut kontrol diri remaja, namun dengan kepekaan yang kurang terhadap kebutuhan remaja tersebut, yang dapat menyebabkan rendahnya pencapaian pada remaja tersebut. Pola asuh permissive didefinisikan sebagai pola asuh yang tidak terlalu menuntut kontrol diri dan disiplin sebagai pencapaiannya, namun orang tua terlalu peka dan cenderung menuruti keinginan remaja tersebut. Pola ini dapat menyebabkan tingginya kepercayaan diri remaja tersebut, dengan tingginya kecenderungan remaja melakukan tindakan beresiko. Orang tua yang menerapkan pola asuh neglectful akan cenderung menyebabkan remaja mengalami pencapaian diri yang rendah, bahkan sangat rentan terhadap perilaku beresiko. Hal ini berhubungan oleh karakteristik pola asuh neglectful yang tidak memerhatikan kepekaan orang tua terhadap kebutuhan remaja, dan kurangnya keinginan orang tua untuk menjadikan remaja tersebut memiliki kontrol diri yang tinggi yang akan semakin meningkatkan kemungkinan remaja melakukan perilaku beresiko, bahkan mengarah kepada perilaku pidana.

Perilaku kriminalitas pada awal tahun 2013 didominasi oleh pelajar yang berusia remaja, dengan kasus berupa pencurian, tindakan asusila, tawuran, hingga kasus narkoba (Yamin \& Teguh, 2013). Data Profil Kriminalitas Remaja 2010 (Hasinta, 2010), mengungkapkan bahwa selama tahun 2007 tercatat sekitar 3.100 orang pelaku remaja berusia 18 tahun atau kurang. Jumlah itu meningkat pada tahun 2008 menjadi 3.300 pelaku dan menjadi 4.200 pelaku pada 2009 . Hasil analisis data yang bersumber dari berkas laporan penelitian kemasyarakatan (Irwansyah, 2013), mengungkapkan bahwa sebesar $81,5 \%$ pelaku kriminalitas ini berasal dari keluarga yang kurang atau tidak mampu secara ekonomi. Adapun tindak pidana terbanyak yang dilakukan remaja tersebut adalah tindak pencurian $(60 \%)$ dengan faktor ekonomi sebagai pemicunya. Sementara itu, ketua Komisi Perlindungan Anak Aris Merdeka Sirait mengungkapkan, setidaknya terdapat sekitar 7.000 lebih anak yang mendekam di penjara. Adapun empat kasus yang mendominasi kasus kenakalan remaja ini, adalah narkotika, pelecehan seksual, pencurian dan pembunuhan, serta terdapat 12 kasus pembunuhan sepanjang tahun 2012 (Irwansyah, 2013).

Seorang remaja yang berusia kurang dari 18 tahun dan terbukti secara hukum melakukan tindak pidana, tidak akan mendapatkan hukuman di dalam penjara seperti yang dialami orang dewasa yang terbukti secara hukum telah melakukan tindak pidana, melainkan akan mendapatkan pembinaan di dalam lembaga pemasyarakatan anak dengan sebutan anak pidana. Hal tersebut dijelaskan dalam UndangUndang Republik Indonesia Nomor 12 Tahun 1995 yang mengatur tentang pemasyarakatan.

Memasuki sebuah tempat pembinaan bernama lembaga pemasyarakatan sudah tentu membuat citra bahkan labelling tersendiri pada masyarakat, sehubungan dengan perilaku-perilaku melanggar hukum dan norma yang pernah dilakukan oleh para penghuni lembaga pemasyarakatan yang memiliki sebutan narapidana tersebut. Berdasarkan hasil preliminary study (Dewi, 2012), berupa wawancara informal yang peneliti lakukan terhadap 5 orang secara acak, ternyata label "orang bermasalah" tersebut tidak sekaligus dihentikan meskipun seorang narapidana telah menghabiskan masa hukumannya dan kembali ke tengah masyarakat. Kata "penjahat" mempunyai konotasi buruk terhadap perkembangan remaja dan tentunya label ini akan melekat dalam dirinya yang kemudian akan berpengaruh terhadap kepribadian remaja (Yulia dalam Handayani, 2010), sehingga saat memasuki lembaga pemasyarakatan tersebut, para anak pidana akan mengalami perubahan pola hidup baik dari segi fisik maupun psikologis dalam menghadapi segala dinamika kehidupan dalam lembaga pemasyarakatan anak yang ada.

Berdasarkan pendapat lima orang responden yang dipilih secara acak dan beberapa anak pidana di Lembaga Pemasyarakatan Anak Kelas II B Karangasem (Dewi, 2012), memasuki kehidupan di dalam lembaga pemasyarakatan anak pada awalnya merupakan suatu "penderitaan" yang bahkan mampu menimbulkan depresi. Penderitaan tersebut dapat berupa mengalami tekanan akibat kegiatan di dalam lapas anak yang monoton dan terbatasnya akses di dalam lapas anak, yang berbanding terbalik dengan kondisi anak pidana tersebut sebelum menjalani kegiatan pembinaan di dalam lapas anak. Untuk bertahan dalam kondisi depresi tersebut, seseorang seharusnya dapat memaknai kehidupan dibalik penderitaan tersebut, atau setidaknya memahami alasan hidupnya, karena ketika seseorang mengetahui makna hidupnya, hal tersebut dapat menjadi motivator utama yang membuat individu bertahan meskipun dalam penderitaan. 


\section{A. A. S. S. DEWI DAN D. H. TOBING}

Ketika seseorang menemukan makna hidup, hidup pun dapat dijalani dengan lebih semangat, tetapi penemuan makna hidup itu sendiri tidak semudah membalikkan telapak tangan, melainkan suatu proses yang panjang. Hal inilah yang membuat peneliti tertarik untuk mencari tahu apa sajakah kebermaknaan hidup anak pidana tersebut selama di lembaga pemasyarakatan anak.

\section{METODE}

\section{Tipe Penelitian}

Penelitian ini menggunakan metode penelitian kualitatif. Metode penelitian kualitatif sering disebut metode penelitian naturalistik karena penelitiannya yang dilakukan pada setting dan objek alamiah (Sugiyono, 2012).

Desain yang digunakan dalam penelitian ini adalah fenomenologi. Fenomenologi adalah penelitian yang mencoba menjelaskan atau mengungkap makna konsep atau fenomena pengalaman yang didasari oleh kesadaran yang terjadi pada beberapa individu (Moleong, 2012).

Fenomenologi digunakan sebagai tipe penelitian ini didasarkan pada beberapa prinsip mengenai metode ini menurut Ghony dan Almanshur (2012), antara lain:

1. Dalam penelitian ini, peneliti akan melihat kebermaknaan hidup anak pidana terkait dengan pengalamanpengalaman yang dialami selama berada di dalam lembaga pemasyarakatan anak.

2. Penelitian ini bertujuan untuk mengetahui apakah kebermaknaan hidup anak pidana yang terepresentasikan dalam pengalaman hidup sehari-harinya.

3. Studi fenomenologi mempelajari sebuah fenomena atau konsep berdasarkan sudut pandang dan keyakinan langsung dari individu atau kelompok individu sebagai subjek yang mengalami langsung. Inilah sebabnya subjek yang dipilih adalah anak pidana, agar mendapatkan pemahaman mengenai kebermaknaan hidup berdasarkan sudut pandang mereka yang menjalani "hukuman" di lembaga pemasyarakatan anak tersebut.

\section{Unit Analisis}

Unit analisis penelitian ini dapat dibagi ke dalam dua tahapan, yaitu unit analisis kelompok pada saat peneliti mencari pandangan awal anak pidana mengenai kebermaknaan hidup, serta unit analisis individu saat peneliti menggali secara mendalam mengenai pandangan masingmasing anak pidana yang menjadi subjek penelitian ini, terhadap kebermaknaan hidup selama berada di dalam Lembaga Pemasyarakatan Anak Kelas II B Karangasem. Pandangan mengenai kebermaknaan hidup tersebut terkait dengan keenam aspek dasar kebermaknaan hidup yang dipaparkan oleh James Crumbaugh dan Leonard Maholick (dalam Suyatno, 2011), namun tidak menutup kemungkinan akan ada aspek lain yang terungkap, disesuaikan dengan data yang diperoleh di lapangan. Unit-unit analisis ini akan diperoleh melalui focus group discussion dan in-depth interview dengan menggunakan panduan pertanyaan yang terkait dengan aspek-aspek kebermaknaan hidup tersebut.

\section{Subjek Penelitian}

Secara keseluruhan, subjek yang paling banyak terlibat dalam penelitian ini adalah anak pidana yang menjalani masa hukumannya di Lembaga Pemasyarakatan Kelas II B Karangasem. Dalam penelitian ini, anak pidana menjadi subjek dengan tujuan untuk mendapatkan pemahaman mengenai kebermaknaan hidup berdasarkan sudut pandang mereka yang mengalami "hukuman" di lembaga pemasyarakatan tersebut. Adapun beberapa kriteria inklusi dari subjek penelitian ini sesuai dengan tahapan pengambilan datanya, adalah:

a. Dalam preliminary study, subjek yang digunakan adalah 5 orang remaja berusia 16-20 tahun yang dipilih secara acak untuk mengetahui persepsi mereka mengenai remaja seusia mereka yang harus menjalani pembinaan di dalam lembaga pemasyarakatan anak,

b. Seluruh anak pidana Lembaga Pemasyarakatan Kelas II B Karangasem yang berusia 16-21 tahun diikutsertakan dalam kegiatan focus group discussion (FGD) untuk mendapatkan pandangan awal mengenai kebermaknaan hidup mereka,

c. Tiga orang anak pidana yang telah berada di dalam lapas anak Karangasem selama di atas 4 bulan dan tiga orang anak pidana yang telah berada di dalam lapas anak Karangasem selama di bawah 4 bulan akan diikutkan dalam in-depth interview untuk mendapatkan pandangan komprehensif tentang apakah kebermaknaan hidup anak-anak pidana ini. Keenam anak ini akan dipilih berdasarkan jawaban-jawaban yang mereka berikan saat FGD berlangsung, yang menurut peneliti representatif terhadap topik dan memiliki keunikan tersendiri.

\section{Teknik Penggalian Data}

Variabel Untuk mendapatkan data yang reliabel, beberapa teknik penggalian data akan digunakan dalam penelitian ini. Teknik pertama adalah focus group discussion. Focus group discussion (FGD) berarti interaksi kelompok yang dinamis di dalam suatu percakapan yang memiliki suatu tujuan (Ghony \& Almanshur, 2012). Sesuai dengan paparan tersebut, FGD dalam penelitian ini dilakukan untuk mengetahui pendapat atau persepsi anak pidana mengenai kebermaknaan hidup secara umum. Peneliti akan mengikutsertakan anak-anak pidana yang berusia 16-21 tahun dalam FGD ini. Pelaksanaan FGD akan dibagi ke dalam beberapa kelompok. Pembagian sesi dan kelompok dilakukan 
berdasarkan kurun waktu anak pidana tersebut. Dalam proses FGD ini, pertanyaan yang diberikan kepada responden akan tersaji dalam sebuah pedoman pertanyaan mengenai enam aspek kebermaknaan hidup oleh James Crumbaugh dan Leonard Maholick (dalam Suyatno, 2011).

Setelah mendapatkan data awal yang merupakan jawaban-jawaban reperesentatif dan unik dari sesi FGD, peneliti akan menggunakan metode wawancara semi terstruktur yang termasuk ke dalam kategori in-depth interview di mana pedoman pertanyaan dari wawancara ini tidak terlalu terstruktur dan peneliti akan bertanya lebih lanjut lagi jika jawaban dari pertanyaan kepada sumber dianggap belum cukup representatif. Jumlah partisipan sesi in-depth interview ini tidak akan sebanyak sesi FGD, karena peneliti hanya akan menggali jawaban yang lebih mendalam pada jawaban-jawaban representatif namun unik yang diberikan oleh beberapa partisipan sesi FGD.

Subjek yang dipilih dalam sesi ᄀin-depth interview ini sebanyak enam orang yang memiliki jawaban yang unik dan representatif atas pertanyaan-pertanyaan yang diajukan pada sesi FGD. Subjek terbagi dalam dua kelompok, yaitu 3 orang anak pidana yang telah berada di dalam lapas anak Karangasem selama di atas 4 bulan dan 3 orang anak pidana yang telah berada di dalam lapas anak Karangasem selama di bawah 4 bulan. Seperti pada sesi FGD, sesi in-depth interview juga menggunakan suatu pedoman pertanyaan mengenai kebermaknaan hidup, namun kali ini telah peneliti sesuaikan dengan hasil yang diperoleh dari FGD.

Metode penggalian data yang digunakan selanjutnya adalah metode observasi. Observasi partisipasi moderat akan digunakan dalam penelitian ini. Dalam observasi ini, terdapat keseimbangan antara peneliti menjadi orang dalam dengan orang luar. Peneliti mengumpulkan data dengan mengikuti beberapa kegiatan subjek, namun tidak semuanya (Ghony \& Almanshur, 2012). Hal ini terkait dengan ijin yang diberikan pihak Lembaga Pemasyarakatan Anak Kelas II B Karangasem, yang mempertimbangkan faktor keamanan peneliti, sehingga waktu pengamatan dan kegiatan yang dapat diamati peneliti terbatas.

Hal-hal yang diamati peneliti merupakan hal-hal yang dapat merepresentasikan enam aspek kebermaknaan hidup menurut James Crumbaugh dan Leonard Maholick (dalam Suyatno, 2011), namun tidak menutup kemungkinan jika didapatkan perilaku-perilaku lainnya yang dapat merepresentasikan aspek kebermaknaan hidup lainnya. Hasil observasi nantinya akan dilaporkan dengan menggunakan metode naratif, dan perilaku subjek yang muncul akan disajikan dalam sebuah kalimat atau paragraf.

\section{Teknik Pengorganisasian dan Analisis Data}

Setelah seluruh data temuan terkumpul, peneliti akan mengorganisasikan data temuan ke dalam suatu folder, agar tersusun rapi. Data temuan berupa rekaman suara akan ditransfer ke dalam bentuk teks dalam format dokumen, dengan mengetik setiap suara yang terdengar. Data pengamatan yang berupa tulisan dan simbol juga ditransfer ke dalam bentuk teks dalam format dokumen, dengan mengetik setiap data yang tertulis, kemudian memilih data yang memiliki makna. Seluruh data temuan yang telah berbentuk teks akan disusun untuk masing-masing subjek penelitian. Data temuan yang telah tersusun, akan dikategorisasikan sesuai dengan tema dalam penelitian ini, yaitu enam aspek dasar kebermaknaan hidup (Crumbaugh \& Maholick dalam Suyatno, 2011). Jika terdapat data yang memiliki keterkaitan dengan kebermaknaan hidup, namun tidak termasuk ke dalam enam aspek dasar, maka akan dilakukan kategorisasi dan analisis terhadap data tersebut dengan menggunakan teknik analisis tematik (Tobing, 2006) dan teknik analisis yang diungkapkan Miles dan Huberman (dalam Ghony \& Almanshur, 2012)

Menurut Miles dan Huberman (dalam Ghony \& Almanshur, 2012), terdapat tiga langkah analisis data, yaitu:

a. Data reduction atau reduksi data yang berarti merangkum, memilih hal-hal yang pokok, memfokuskan pada hal-hal yang penting, mencari tema dan polanya.

b. Data display atau penyajian data, merupakan tahap penyajian data penelitian baik dalam bentuk uraian singkat, bagan, hubungan antar kategori, flowchart, dan sebagainya. Bentuk yang paling sering digunakan dalam penyajian data adalah teks yang bersifat naratif. Langkah ini akan memudahkan untuk memahami apa yang terjadi dan merencanakan kerja selanjutnya.

c. Conclusion drawing atau verifikasi merupakan langkah ketiga dalam analisis data penelitian kualitatif menurut Miles dan Huberman (dalam Ghony \& Almanshur, 2012). Kesimpulan awal yang dikemukakan dalam penelitian kualitatif masih bersifat sementara dan akan berubah apabila tidak ditemukan bukti-bukti yang kuat dan mendukung pada tahap pengumpulan data berikutnya. Tetapi apabila kesimpulan yang dikemukakan pada tahap awal didukung dengan bukti-bukti yang valid dan konsisten saat peneliti kembali ke lapangan mengumpulkan data, maka kesimpulan yang dikemukakan merupakan kesimpulan yang kredibel (Sugiyono, 2012).

Teknik analisis selanjutnya yang digunakan dalam penelitian ini adalah teknik analisis tematik (Tobing, 2006). Peneliti akan memulai dengan melakukan teknik open coding, yaitu penguraian data tertulis dari verbatim dan catatan lapangan yang dilakukan untuk mencari segala kemungkinan makna yang dapat muncul. Kode yang disusun selama proses open coding ini, akan menggunakan kata-kata yang sesuai dengan dasar keilmuan penelitian yang bersangkutan, sehingga kode tersebut akan lebih jelas secara konstruk dan 
lebih sistematis, atau yang sering disebut dengan sociological construct (Strauss, 2003).

Teknik selanjutnya yang dilakukan adalah axial coding, dengan menyatukan kembali kalimat hasil dari pencarian makna pada open coding agar terlihat sebuah hubungan awal antar kategori awal. Selective coding merupakan tahap akhir dari tahapan analisis tematik. Pada tahapan ini, peneliti akan merangkai suatu kalimat hasil temuan yang merupakan inti dari kalimat pada axial coding. Setelah mendapatkan inti kalimat tersebut, peneliti akan melakukan pengecekan ulang pada subjek wawancara dan tenaga profesional, sehingga kategori inti tersebut merupakan hasil dari rangkuman kenyataan di lapangan dan terlepas dari interpretasi peneliti (Tobing, 2006).

\section{Teknik Pemantapan Kredibilitas Penelitian}

Pemantapan kredibilitas dalam penelitian kualitatif dapat dilakukan dengan berbagai cara. Berikut adalah paparan teknik uji kredibilitas menurut Sugiyono (2012) yang disesuaikan dengan penelitian ini:

a. Perpanjangan pengamatan. Dalam proses ini, peneliti akan kembali ke lapangan, melakukan pengamatan, dan wawancara kembali terhadap subjek yang pernah ditemui maupun yang baru. Metode ini bertujuan untuk semakin membentuk rapport, dengan asumsi para anak pidana ini akan semakin akrab, semakin terbuka, dan saling memercayai sehingga tidak akan ada informasi yang disembunyikan lagi. Peneliti dalam penelitian ini akan melakukan beberapa kali pengamatan terhadap subjek yang sama dan proses wawancara yang diawali dengan focus group discussion, kemudian dilanjutkan pada proses in-depth interview.

b. Triangulasi. Metode ini merupakan pengecekan data dari berbagai sumber, dengan berbagai cara dan berbagai waktu. Peneliti akan melakukan triangulasi sumber yang merupakan pengumpulan data dari beberapa sumber, yaitu 3 orang anak pidana yang masa tahanannya di atas 4 bulan dan 3 orang anak pidana dengan masa tahanan di bawah 4 bulan. Triangulasi teknik juga akan dilakukan peneliti dengan melakukan beberapa metode pengumpulan data yang berbeda, yaitu focus group discussion, in-depth interview, dan teknik observasi.

c. Analisis kasus negatif. Dalam metode ini, peneliti akan mencari data yang berbeda atau bahkan bertentangan dengan data yang telah ditemukan. Oleh karena itu, penelitian ini menggunakan 3 subjek pada masing-masing kelompok untuk dapat dianalisa adanya perbedaan temuan atau tidak mengenai kebermakaan hidup para subjek.

d. Menggunakan bahan referensi. Penggunaan bahan referensi adalah penggunaan bahan pendukung untuk membuktikan data yang telah ditemukan oleh peneliti. Dalam penelitian ini, alat pendukung yang digunakan adalah kamera dan alat rekam suara, agar data yang didapatkan bisa lebih dipercaya.

\section{HASIL PENELITIAN}

Berdasarkan temuan yang didapatkan pada saat wawancara informal, observasi, focus group discussion, dan in-depth interview, peneliti mendapatkan enam aspek kebermaknaan hidup bagi anak pidana Lembaga Pemasyarakatan Anak Kelas II B Karangasem, yaitu kepuasan hidup, hal yang paling berarti dalam hidup, penerimaan terhadap hidup di dalam lapas, kebebasan, kepantasan hidup, dan perubahan yang dialami selama di dalam lapas. Sebelum mendapatkan keenam aspek kebermaknaan hidup ini, peneliti telah melakukan proses analisis tematik sehingga temuantemuan dalam penelitian ini terbagi ke dalam beberapa tema yang selanjutnya peneliti sebut dengan aspek dari kebermaknaan hidup.

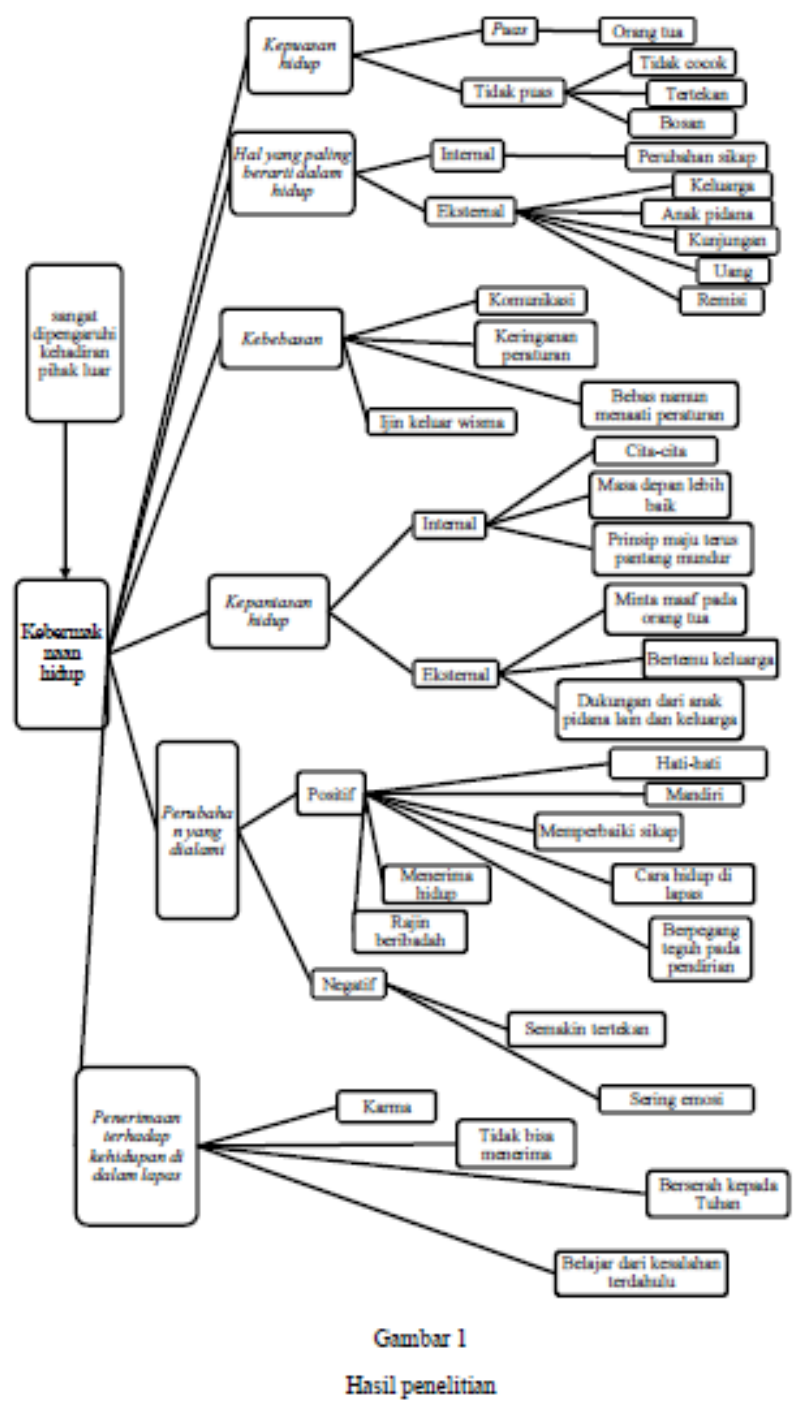




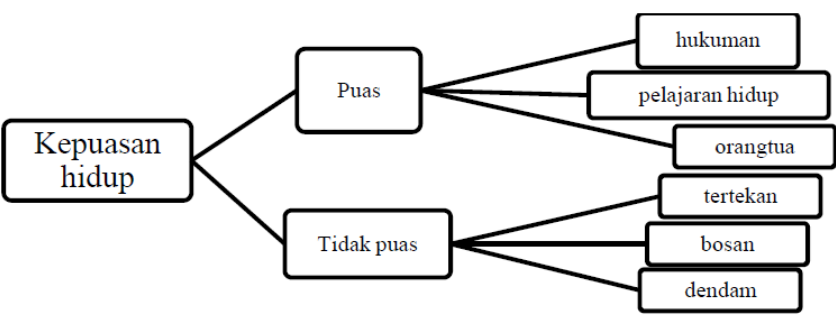

Gambar 2

Bagan aspek kepuasan hidup

Jika dilihat dari segi kepuasan hidup, terdapat tiga orang subjek yang merasa puas dengan kehidupan selama di dalam lapas, sedangkan tiga subjek lainnya merasa tidak puas dengan kehidupan di dalam lapas anak. Ketiga subjek merasa puas, karena selama di dalam lapas orang tua subjek masih bersedia untuk menunggu, menyayangi dan tidak malu terhadap subjek walaupun telah melakukan suatu pelanggaran yang membuat subjek mendapatkan pembinaan di dalam lapas. Kepuasan juga dirasakan akibat adanya keuntungan berada di dalam lapas anak, yaitu tidak perlu mendapatkan hukuman lebih lama, dengan pertimbangan bahwa subjek masih berusia di bawah umur. Selain itu, subjek juga dapat merasakan kepuasan karena subjek mendapatkan banyak pelajaran hidup selama di dalam lapas, bisa memperbaiki hidup sesuai dengan agama dan hukum, serta mendapat pengalaman baru dari kunjungan pihak luar.

Tiga orang subjek lainnya merasakan ketidakpuasan dan bahkan merasa tertekan terhadap keberadaan subjek di dalam Lembaga Pemasyarakatan Anak Kelas II B Karangasem. Perasaan tertekan muncul karena menurut subjek, subjek tidak seharusnya diberikan pembinaan di dalam lapas anak jika dilihat dari usia subjek. Subjek juga merasa tidak dapat beradaptasi dengan pola pikir anak pidana lainnya yang cenderung kekanak-kanakan yang akhirnya membuat subjek merasa tertekan. Rasa tidak puas juga dirasakan para subjek karena monotonnya kegiatan yang dapat dilakukan di dalam lapas. Perasaan dendam terhadap beberapa orang yang berlaku tidak baik terhadap subjek juga menjadi salah satu penyebab para subjek tidak merasakan kepuasan selama berada di dalam lapas anak.

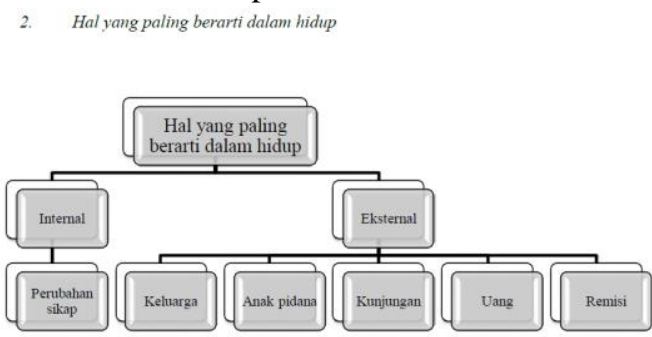

Gambar 3

Bagan aspek hal yang paling berarti dalam hidup
Salah satu faktor yang berhubungan dengan kebermaknaan hidup para anak pidana di Lembaga Pemasyarakatan Anak Kelas II B Karangasem adalah adanya hal-hal yang paling berarti bagi para subjek selama hidup di dalam lapas anak. Keluarga merupakan sosok paling berarti bagi beberapa subjek, terkait dengan kebahagiaan adik perempuan, kakek, dan nenek subjek. Subjek merasa sosoksosok ini telah berjasa dalam menemani hidup subjek, sehingga subjek merasa perlu untuk berterima kasih dengan rela berkorban apapun demi kebahagiaan mereka. Nasihat dari ayah pun menjadi sangat berarti, karena selalu menjadi pedoman subjek dalam menjalani hidup, yang berisi tentang bagaimana cara menghadapi kehidupan di dalam lapas yang terkenal keras, serta bagaimana ayah subjek yang selalu mengingatkan subjek untuk bersikap yang baik selama menjalani masa pembinaan di dalam lapas anak.

Dukungan serta saran yang diberikan rekan sesama anak pidana dapat membuat hidup yang dijalani subjek terasa lebih berarti selama berada di dalam Lembaga Pemasyarakatan Anak Kelas II B Karangasem. Selain itu, kunjungan dari pihak luar sangat berarti bagi beberapa subjek selama berada di dalam lapas, terkait dengan suasana baru yang dirasakan subjek dengan kehadiran pihak luar, sehingga dapat mengurangi penderitaan subjek di dalam lapas meskipun untuk waktu yang singkat.

Selain keberadaan pihak-pihak tersebut, keberadaan uang juga menjadi salah satu hal yang dapat membuat kehidupan beberapa subjek menjadi lebih bermakna, untuk mencukupi kebutuhan sehari-hari anak pidana yang kurang dipenuhi oleh pihak lapas. Salah satu subjek bahkan menyatakan, jika berkaitan dengan uang, subjek akan memilih untuk menjalani sisa masa hukuman di Lembaga Pemasyarakatan Kelas II A Denpasar karena di lapas tersebut subjek masih bisa menghasilkan uang meskipun harus melakukan cara-cara yang ilegal dan cenderung berbahaya. Perubahan sikap ke arah yang lebih baik adalah hal lainnya yang dianggap paling berarti oleh beberapa subjek. Adanya perubahan sikap yang lebih positif dan bertahan lama ini, diharapkan agar remisi dan pembebasan bersyarat akan segera didapatkan subjek-subjek tersebut.
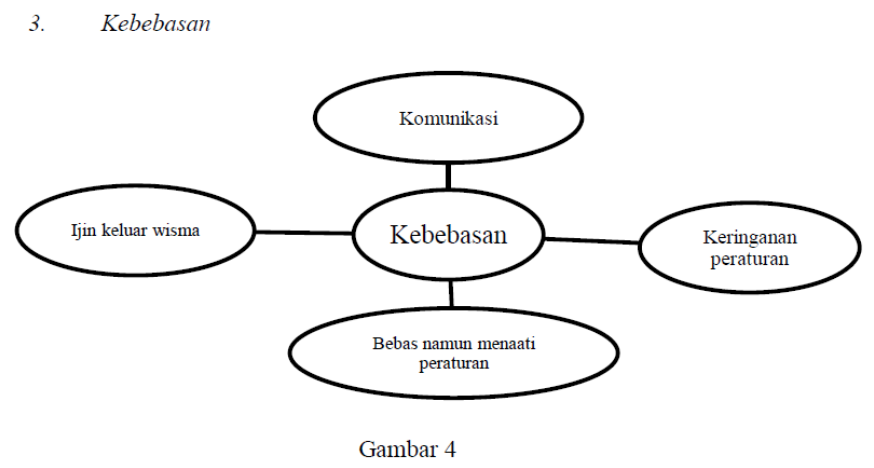

Bagan aspek kebebasan 


\section{A. A. S. S. DEWI DAN D. H. TOBING}

Terdapat beberapa hal terkait dengan kebebasan yang dapat membuat hidup para subjek menjadi lebih berarti selama berada di dalam lapas anak. Kebebasan untuk membawa handphone merupakan salah satunya. Handphone dianggap penting bagi para subjek untuk menghubungi dan mengetahui kabar keluarga, meskipun hal tersebut merupakan suatu larangan bagi para anak pidana.

Keringanan terhadap peraturan yang mengancam anak pidana mendapatkan hukuman di dalam sel sangat diharapkan oleh hampir seluruh subjek. Hukuman di dalam sel ini berarti, jika terdapat anak pidana yang melanggar peraturan di dalam lapas, akan dikenakan hukuman di dalam sel karantina yang akan mengisolasi para anak pidana yang bersalah dari segala akses dengan dunia luar, termasuk rekan anak pidana lainnya, tidak diperbolehkan untuk menerima besukan dari siapapun selama beberapa waktu. Salah satu peraturan yang dianggap terlalu ketat adalah larangan merokok bagi anak pidana yang belum masuk dalam kategori “dewasa". Para subjek menganggap bahwa peraturan ini terlalu berlebihan, karena di rumah pun tidak pernah ada yang melarang subjek untuk merokok termasuk orangtua subjek. Sehingga hukuman tersebut menyebabkan subjek merasa sangat dibatasi dalam melakukan sesuatu dan subjek merasa tidak bahagia selama di dalam lapas.

Menurut subjek lainnya, kebebasan untuk melakukan suatu hal merupakan hal yang penting selama berada di dalam lapas, selama subjek tetap mematuhi peraturan yang berlaku, namun subjek tidak menuntut kebebasan yang berlebihan, karena menyadari posisi subjek saat ini sebagai pihak yang sedang mendapatkan pembinaan di bawah pengawasan negara dan undang-undang.

Mendapatkan ijin keluar wisma yang merupakan lingkungan tempat tinggal para anak pidana, merupakan suatu hal yang sangat diharapkan hampir seluruh subjek, meskipun untuk melakukan hal kecil seperti membersihkan lingkungan. Hal tersebut diharapkan subjek mampu mengatasi kebosanan terhadap suasana di dalam Lembaga Pemasyarakatan Anak Kelas II B Karangasem yang monoton. Mendapatkan ijin keluar wisma bukanlah suatu hal yang mudah didapatkan anak pidana. Para anak pidana harus mendapatkan kepercayaan dari para petugas lapas, sehingga berkelakuan baik dan kooperatif merupakan suatu syarat mutlak yang wajib dilakukan para anak pidana terutama subjek untuk mendapatkan ijin keluar tersebut.
4. Kepantasan hidup

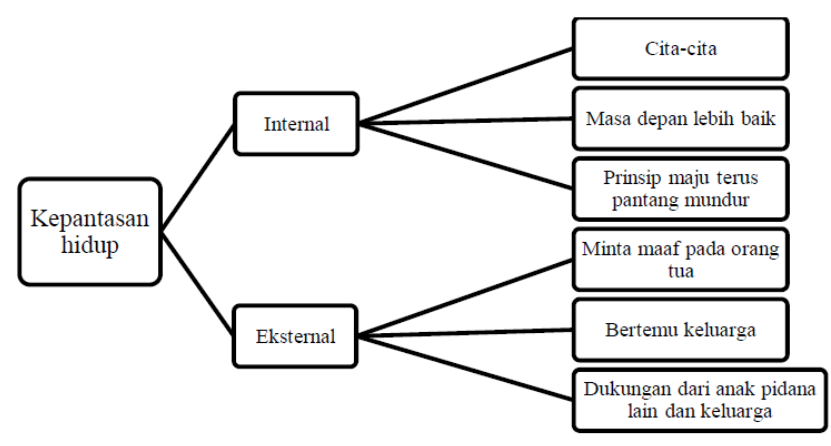

Gambar 5

Bagan aspek kepantasan hidup

Kepantasan untuk hidup merupakan salah satu aspek yang paling unik dalam penelitian ini. Aspek ini membahas mengenai hal-hal yang membuat anak pidana merasa pantas untuk melanjutkan kehidupan yang dijalani dengan segala keterbatasan yang dirasakan selama berada di dalam lapas anak. Salah satu subjek bahkan tidak merasa pantas untuk mementingkan kehidupan pribadi sebelum bertanggung jawab terhadap kehidupan adik perempuan, nenek, dan kakek subjek. Hal tersebut terjadi karena subjek merasa memiliki hutang terhadap adik perempuan, nenek, dan kakek yang sejak kecil telah merawat dan menyayangi subjek, dan tetap memberi dukungan kepada subjek meskipun subjek pernah melakukan perbuatan melanggar hukum hingga menjalani pembinaan di dalam lembaga pemasyarakatan. Subjek akan tetap bertanggung jawab terhadap kehidupan adik perempuan subjek, hingga adik perempuannya mampu mengusahakan hidupnya sendiri.

Beberapa subjek merasa pantas untuk tetap bertahan hidup, karena subjek masih optimis dengan perubahan yang dapat terjadi pada masa depan subjek, masih adanya keinginan untuk meraih cita-cita yang belum tercapai, dan keinginan subjek untuk meminta maaf kepada orangtua subjek, karena perilaku melanggar hukum yang pernah dilakukan subjek yang menyebabkan subjek menjalani hukuman di dalam lembaga pemasyarakatan. Beberapa subjek lain juga tidak pernah menyesali keberadaannya di dalam lapas, karena hal tersebut telah setimpal dengan perbuatan melanggar hukum yang subjek lakukan.

Subjek lainnya merasa pantas untuk melanjutkan hidup karena memiliki keinginan untuk bertemu dan meminta maaf kepada orangtua dan keluarga subjek, yang menunggu subjek di rumah. Subjek menjalani hidup di dalam lapas dengan menggunakan prinsip "jurus tandur" atau prinsip maju terus pantang mundur dalam bahasa Indonesia, yang berarti bahwa subjek tidak akan menyerah terhadap hidup dan segala hal yang dialami.

Baik dari hasil in-depth interview, wawancara informal, maupun focus group discussion, didapatkan bahwa tidak ada satupun anak pidana yang menyetujui usaha 
mengakhiri hidup selama berada di dalam lapas dengan bunuh diri karena para anak pidana ini sesungguhnya masih memiliki masa depan yang panjang untuk menjalani hidup yang lebih baik.

5. Perubahan yang dialami

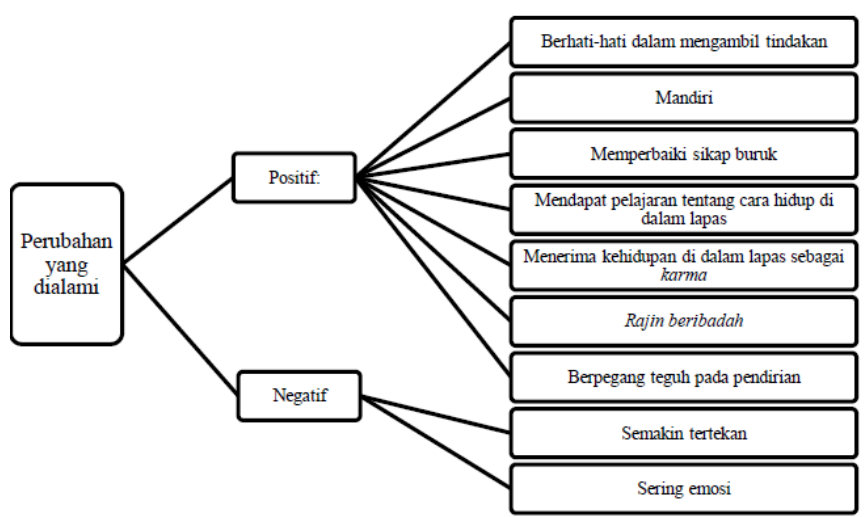

Gambar 6

Bagan aspek perubahan yang dialami

Sebagian besar subjek merasa mengalami perubahan selama berada di dalam lapas dengan mencapai hidup yang lebih baik dari sebelumnya, salah satunya dengan lebih berhati-hati dalam mengambil tindakan. Subjek yang dulunya hanya memedulikan masa sekarang, dan terkesan sangat tidak bertanggung jawab karena tidak pernah memikirkan mengenai konsekuensi perbuatan tersebut, sekarang telah menyadari bahwa subjek masih memiliki tanggung jawab terhadap kehidupan keluarga subjek, sehingga subjek akan selalu mempertimbangkan secara hati-hati langkah yang akan subjek ambil agar tidak merugikan siapapun.

Perubahan positif juga dialami beberapa subjek lain dengan menjadi individu yang lebih mandiri, mampu memperbaiki sikap buruk, dan merasa mendapatkan pelajaran tentang sikap selama menjalani pembinaan di dalam lapas. Beberapa subjek juga menjadi lebih rajin beribadah untuk menenangkan diri ketika ada masalah yang subjek hadapi. Subjek lain berubah dengan menjadi tidak terpengaruh dengan kerasnya kehidupan di dalam lapas dan selalu berpegang teguh pada keyakinan subjek untuk selalu berperilaku positif.

Tidak hanya perubahan positif yang dialami para anak pidana di dalam lapas anak, namun ada juga yang merasakan perubahan ke arah negatif. Salah sutnya adalah perasaan semakin tertekan akibat keberadaan subjek di dalam lapas anak. Subjek merasa tertekan karena merasa tidak pantas berada di dalam lapas anak, mengingat usia subjek yang tidak dapat digolongkan ke dalam usia anak-anak lagi, dan juga karena pola pikir anak pidana lain yang menurut subjek masih terlalu kekanak-kanakan, sehingga subjek sulit untuk beradaptasi dan merasa tertekan. Perubahan negatif lainnya adalah salah satu subjek yang masih sering merasakan emosi negatif ketika bertemu dengan orang yang tidak menyukai subjek.
6. Penerimaan terhadap kehidupan di dalam lapas

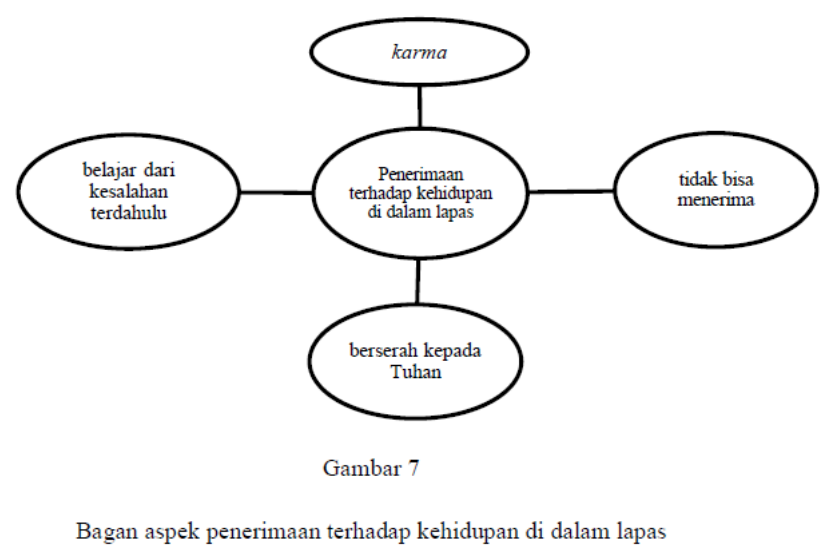

Sebagian besar subjek telah mampu menerima dan bahkan bersyukur atas hukuman dan kehidupan di dalam lapas sebagai karma terhadap perbuatan melanggar hukum yang telah dilakukan. Kesadaran tersebut juga membuat para anak pidana mampu belajar dari kesalahan yang pernah mereka lakukan.

Salah satu anak pidana masih belum mampu menerima kehidupan subjek di dalam lapas, namun subjek memilih untuk tetap bertahan hidup di dalam lapas karena pesan yang disampaikan oleh nenek subjek, dan prinsip bahwa kehidupan selama di dalam lapas sebagai "roda yang sedang berputar". Hal tersebut berarti bahwa kehidupan manusia akan mengalami perputaran, dengan sesekali berada pada titik tertinggi dan sesekali berada pada titik terendah, dan kehidupan di dalam lapas ini merupakan suatu titik terendah bagi subjek.

Berdasarkan temuan-temuan yang didapatkan, peneliti menemukan suatu keunikan di mana kebermaknaan hidup bagi anak pidana di Lembaga Pemasyarakatan Anak Kelas II B Karangasem sangat terkait dengan pengaruh pihak luar, seperti orangtua dan keluarga lainnya, serta rekan sesama anak pidana, meskipun fokus dari penelitian ini adalah kebermaknaan hidup bagi diri anak pidana itu sendiri. Sistem kolektivis yang menempatkan kepentingan kelompok di atas kepentingan pribadi, merupakan sebuah budaya bagi sebagian masyarakat Indonesia yang telah ditanamkan sejak kecil oleh para orang tua. Budaya ini pun berpotensi memiliki pengaruh pada pola pikir para anak pidana yang juga akan memengaruhi kebermaknaan hidupnya.

Aspek hal yang paling berarti dan kepantasan hidup merupakan aspek-aspek yang menurut peneliti memiliki keunikan lebih dari keempat aspek kebermaknaan hidup lainnya. Aspek hal yang paling berarti ini peneliti anggap unik karena ternyata yang paling berarti bagi para anak pidana ini adalah pihak di luar diri subjek sendiri, yaitu orangtua dan sesama anak pidana di Lembaga Pemasyarakatan Anak Kelas II B Karangasem, serta adanya uang. Aspek kebermaknaan hidup lainnya yang peneliti anggap unik adalah aspek kepantasan hidup. Sebagian dari anak pidana menganggap 


\section{A. A. S. S. DEWI DAN D. H. TOBING}

bahwa hidup mereka masih pantas untuk dilanjutkan karena adanya tujuan hidup yang berhubungan dengan orangtua dan kerabat yang telah merawat dan mendukung para anak pidana selama keberadaan mereka di dalam lapas anak.

\section{PEMBAHASAN DAN KESIMPULAN}

Penelitian ini bertujuan untuk mengungkap dinamika psikologis para anak pidana di Lembaga Pemasyarakatan Kelas II B Karangasem, terkait dengan kebermaknaan hidup. Berdasarkan temuan-temuan yang telah dideskripsikan pada subbab sebelumnya, anak pidana Lembaga Pemasyarakatan Anak Kelas II B Karangasem memaknai kehidupan mereka selama di dalam lapas dengan enam aspek, yaitu dilihat dari kepuasan terhadap hidup selama di dalam lapas, kebebasan yang dirasakan dan diharapkan selama di dalam lapas, perasaan berhak atau pantas untuk melanjutkan hidup di dalam lapas, hal yang paling berarti bagi anak pidana selama berada di dalam lapas anak baik keberadaan seseorang atau materi, perubahan yang dialami selama di dalam lapas, dan penerimaan anak pidana terhadap kehidupan yang dijalani selama berada di dalam lapas anak. Keenam aspek ini dapat dijelaskan melalui teori yang dikemukakan James Crumbaugh dan Leonard Maholick (dalam Suyatno, 2011), tentang enam aspek dasar kebermaknaan hidup.

Aspek-aspek kebermaknaan hidup yang dapat dijelaskan menggunakan keenam aspek dasar ini adalah aspek kepuasan hidup, yang merupakan penilaian seseorang terhadap hidup yang dijalaninya, sejauh mana individu tersebut mampu menikmati dan merasakan kepuasan dalam hidup dan segala aktivitas yang telah dilakukannya. Aspek kebebasan berarti bagaimana individu merasa mampu untuk mengendalikan kebebasan hidupnya secara bertanggung jawab, dan yang dimaksud dengan aspek kepantasan hidup adalah evaluasi individu terhadap hidupnya sendiri, sejauh mana individu merasa bahwa apa yang telah dilalui dalam hidupnya merupakan sesuatu yang wajar, sekaligus menjadi tolok ukur baginya tentang mengapa hidup itu layak untuk diperjuangkan.

Selain itu, keenam aspek kebermaknaan hidup dalam penelitian ini juga dapat dijelaskan melalui pengertian kebermaknaan hidup yang dikemukakan Bastaman (dalam Kartini, 2008) dan Yalom (dalam Cahyani, 2011), yaitu halhal yang dianggap sangat penting dan berharga bagi seseorang, yang dijadikan tujuan hidup untuk dicapai dan dipenuhi, sehingga jika hal tersebut berhasil dipenuhi akan menjadikan seseorang merasakan kehidupan yang berarti dan pada akhirnya akan menimbulkan perasaan bahagia.

Keenam aspek ini juga dapat dikaitkan dengan pengertian kebermaknaan hidup menurut Krueger (dalam Cahyani, 2011), bahwa kebermaknaan hidup adalah suatu cara atau gaya yang digunakan untuk mengada, untuk menghadapi dunia, dan bahwa makna tidak ditentukan oleh situasi, tetapi kita menentukan sendiri makna yang kita berikan pada keadaan. Kebermaknaan hidup adalah suatu hal yang sangat spesifik dan dapat berubah sewaktu-waktu sesuai dengan situasi dan kondisi yang dihadapi individu (Frankl, 2004), sehingga aspek kebermaknaan hidup yang ditemukan pada penelitian ini pun dapat mengalami perubahan apabila dilakukan verifikasi terhadap individu yang sama dalam waktu dan kondisi yang berbeda.

\section{Kepuasan hidup}

Kepuasan hidup merupakan suatu aspek dalam kebermaknaan hidup. Ketika anak pidana menjalani hidup di dalam lapas anak dengan segala keterbatasan yang dihadapi, tentunya para anak pidana ini memerlukan daya resiliensi untuk meminimalkan dampak negatif yang ditimbulkan dari kondisi di dalam lapas. Resiliensi adalah kemampuan yang dimiliki seseorang, kelompok atau masyarakat untuk menghadapi, mencegah, atau meminimalkan dan bahkan menghilangkan dampak-dampak yang merugikan dari kondisikondisi yang tidak menyenangkan, atau bahkan mengubah kondisi kehidupan yang menyengsarakan menjadi suatu hal yang wajar untuk diatasi (Desmita, 2012). Resiliensi juga dikatakan sebagai suatu kemampuan yang sangat dibutuhkan dalam kehidupan terkait dengan kehidupan manusia yang kerap diwarnai oleh kondisi-kondisi yang tidak menyenangkan.

Mikrosistem adalah pihak-pihak yang berhubungan langsung dengan individu yang memiliki pengaruh kuat terhadap kehidupan individu tersebut, terkait dengan adanya reward (penghargaan) sosial, seperti kasih sayang, rasa penerimaan, pertemanan, dan lain-lain yang diberikan oleh pihak tersebut (Brofenbrenner dalam Rice, 2001). Hal ini dapat menjelaskan salah satu subjek dapat merasakan kepuasan hanya dikarenakan memiliki orangtua yang masih menyayangi, tidak malu terhadap subjek meskipun subjek telah melakukan perbuatan melanggar hukum, dan tetap mendukung subjek selama berada di dalam lapas anak. Subjek menganggap bahwa orangtua adalah mikrosistem bagi subjek yang berinteraksi secara langsung, membantu membentuk perasaan self-worth dan secara berkelanjutan memberikan kasih sayang, perhatian, penerimaan, serta mendukung baik secara moral maupun material bagi subjek yang berada pada lingkungan serba terbatas di dalam Lembaga Pemasyarakatan Kelas II B Karangasem.

Terdapat beberapa subjek yang merasa tidak puas selama berada di dalam lapas anak karena ketidaksesuaian pola pikir yang dimiliki subjek dengan anak pidana lainnya yang subjek anggap masih kekanak-kanakan. Hal ini dapat dikarenakan terjadinya identity confusion pada subjek. Identity confusion dapat terjadi pada masa remaja ketika remaja tersebut merasa kebingungan terhadap adanya kekacauan identitas dan peranan akibat sulitnya masa peralihan dari masa anak-anak menuju dewasa dan terjadinya 
kepekaan terhadap perubahan sosial dan historis dalam hidup remaja tersebut (Desmita, 2012). Hal ini pula yang mungkin dialami subjek yang merupakan seorang remaja, bahwa subjek sudah mulai merasakan identitasnya sendiri sebagai seseorang yang sudah dewasa dan tidak seharusnya berada di "dunia" anak-anak kembali. Pola pikir anak pidana lainnya yang cenderung kekanak-kanakan, akan membuat subjek menghindari anak pidana yang subjek anggap memiliki pemikiran kekanak-kanakan, karena hal tersebut dapat mengancam identitas sebagai "orang dewasa" yang mulai dirasakan subjek.

2. Hal yang paling berarti dalam hidup

Seperti kondisi yang telah dipaparkan pada hasil analisis data, ditemukan bahwa kebermaknaan hidup anak pidana di Lembaga Pemasyarakatan Anak Kelas II B Karangasem sangat dipengaruhi oleh kehadiran pihak luar seperti orangtua, nenek, kakek, saudara, dan rekan sesama anak pidana.

Kehadiran sesama anak pidana menjadi berarti selama berada di dalam lapas dapat dikatakan wajar. Hal tersebut dapat terjadi karena pada usia remaja telah terjadi kematangan secara seksual, yang memengaruhi cara pemenuhan emosional seperti pemenuhan kebutuhan cinta, kasih sayang, dan rasa pengertian yang tidak lagi bersumber pada orang tua, tetapi pada rekan lain yang sebaya dan memiliki pola pikir serupa (Rice, 2001). Hal ini pula yang dialami para anak pidana di Lembaga Pemasyarakatan Anak Kelas II B Karangasem. Keberadaan anak pidana lain yang sebaya, berada dalam kondisi serupa yaitu sedang menjalani masa pembinaan di dalam lapas anak, memiliki pola pikir yang hampir serupa, dan selalu memberikan dukungan serta bersedia menjadi rekan yang dapat menjadi tempat untuk berbagi perasaan, dapat menjadikan subjek merasa dihargai, dimengerti, dan diterima, sehingga anak pidana lainnya akan menjadi sangat berarti bagi diri subjek.

Bagi para remaja, masa remaja seharusnya dapat menjadi masa pembentukan identitas diri yang unik dan terlepas dari pengaruh orangtua (Mazor \& Enright dalam Rice, 2001). Namun demikian, hal tersebut tidak terlihat dialami oleh anak pidana yang berada Lembaga Pemasyarakatan Anak Kelas II B Karangasem, yang justru masih sangat bergantung dengan keberadaan orang tua untuk memberikan nasihatnasihat dan dukungan baik secara moral maupun materi. Dalam suatu keluarga atau kelompok yang menerapkan paham kolektivis, kebutuhan, harapan, dan kepentingan kelompok akan diletakkan atau lebih penting daripada kebutuhan, harapan, dan kepentingan diri sendiri. Hal tersebut terjadi karena kolektivisme mengembangkan suasana harmonis, kooperatif, dan konformitas di dalam kelompok (Matsumoto \& Kupperbusch, 2001). Jika dilihat dari konsep kolektivisme yang memiliki tiga aspek ini, diperlukannya dukungan dari orangtua ataupun orang-orang yang merawat mereka, merupakan suatu bentuk konformitas terhadap orangtua atau orang-orang yang merawat mereka tersebut. Kemungkinan para anak pidana ini telah ditanamkan nilai bahwa apa yang dikatakan orang tua akan dapat mengarahkan mereka ke arah kebaikan, sehingga para anak pidana masih bergantung pada nasihat-nasihat yang diberikan orang tua dalam rangka mencari identitas, mencari pegangan atas hidup, serta untuk memaknai kehidupan selama berada di dalam lapas anak.

Mikrosistem adalah pihak-pihak yang berhubungan langsung dengan individu yang memiliki pengaruh kuat terhadap kehidupan individu tersebut, terkait dengan adanya reward (penghargaan) sosial, seperti kasih sayang, rasa penerimaan, pertemanan, dan lain-lain yang diberikan oleh pihak tersebut (Brofenbrenner dalam Rice, 2001). Hal ini dapat menjelaskan pentingnya orangtua, rekan sesama anak didik, dan kerabat yang tetap mendukung subjek selama berada di dalam lapas anak, karena pihak-pihak ini adalah mikrosistem bagi anak pidana yang berinteraksi secara langsung, membantu membentuk perasaan self-worth dan secara berkelanjutan memberikan kasih sayang, perhatian, penerimaan, serta mendukung baik secara moral maupun material bagi anak pidana yang berada pada lingkungan serba terbatas di dalam lapas, sehingga kehadiran pihak-pihak ini pun sangat berpengaruh bagi anak pidana, yang membuat mereka menjadi orang-orang yang paling berarti dalam kehidupan anak pidana selama berada di dalam Lembaga Pemasyarakatan Kelas II B Karangasem.

\section{Kebebasan}

Masa remaja merupakan masa pencarian identitas, yang diikuti dengan dorongan ego yang meningkat. Remaja akan dapat mengidentifikasi identitas yang positif maupun negatif terhadap dirinya (Feist \& Feist, 2009). Identitas tersebut akan berhubungan dengan akan menjadi seperti apa mereka nantinya, hal yang mereka percayai, hal-hal yang tidak diinginkan, dan hal-hal yang tidak mereka percayai. Proses ini terkadang membuat remaja menolak beberapa peraturan yang berlaku yang dianggap tidak sesuai dengan diri individu tersebut, baik peraturan yang diberikan orangtua bahkan negara.

Proses pencarian identitas tersebut juga membutuhkan suatu kebebasan untuk mencari dan mengidentifikasi agar dapat meraih hasil optimal nantinya. Namun di sisi lain, jika disesuaikan dengan kondisi di dalam lapas anak, kebebasan tersebut merupakan suatu hal yang justru sangat sulit didapatkan mengingat segala perilaku mereka telah diatur oleh peraturan negara, sehingga sangat wajar jika anak pidana merasa terkekang. Keinginan untuk dapat keluar wisma untuk sekedar melakukan kegiatan pembersihan pun akhirnya menjadi suatu bentuk kebebasan yang diharapkan beberapa anak pidana, untuk mengatasi dorongan id yang ingin bebas, sekaligus untuk mengatasi 


\section{A. A. S. S. DEWI DAN D. H. TOBING}

kebosanan yang dialami selama keberadaan anak pidana di dalam lapas anak.

Para anak pidana diijinkan untuk menghubungi keluarga mereka melalui telepon yang disediakan pihak lapas meskipun tidak setiap saat dan dengan proses birokrasi yang berbelit, sehingga ijin membawa handphone selama di dalam lapas sangat diharapkan para anak pidana. Membawa alat komunikasi seperti handphone tentunya dilarang di dalam Lembaga Pemasyarakatan Anak Kelas II B Karangasem sesuai dengan peraturan perundang-undangan yang berlaku, sehingga keleluasaan untuk menghubungi keluarga pun menjadi suatu bentuk kebebasan yang sangat diharapkan anak pidana.

\section{Kepantasan hidup}

Dalam sebuah teori kebermaknaan hidup yang dikemukakan Viktor E. Frankl (2004), bahwa manusia akan bertahan untuk tetap hidup bahkan menemui kematian demi meraih impian dan nilai-nilai hidupnya. Teori inilah yang dapat mendasari keinginan kuat para anak pidana untuk tetap melanjutkan hidup selama berada di dalam lapas anak, adalah untuk meraih mimpi dan tujuan hidupnya, seperti membahagiakan orangtua dan orang-orang yang telah mendukung subjek selama ini, keinginan untuk meraih masa depan yang lebih baik, serta keinginan untuk memenuhi tanggung jawab terhadap kehidupan nenek, kakek, dan adik perempuan subjek akibat tugas subjek sebagai seorang anak laki-laki dalam suatu keluarga.

Kebahagiaan keluarga menjadi sebuah prioritas yang harus diwujudkan oleh beberapa orang subjek di atas kebahagiaan mereka sendiri adalah karena para anak pidana ini telah ditanamkan nilai kolektivis, yang menekankan pada kebutuhan, kepentingan, dan harapan kelompok lebih penting daripada kepentingan, harapan, dan kebutuhan individu, dalam rangka mengembangkan suasana harmonis, kooperatif, dan konformitas di dalam individu (Matsumoto \& Kupperbusch, 2001). Dalam hal ini, para anak pidana akan lebih mengusahakan kebahagiaan keluarga dibandingkan kebahagiaan bagi diri mereka sendiri. Besarnya pengaruh nilai kolektivis ini terhadap hidup seorang subjek lainnya, menyebabkan subjek merasa tidak akan memikirkan kepentingan diri subjek sebelum dapat mengusahakan kebahagiaan bagi keluarga subjek.

Keputusan subjek untuk tidak memikirkan kepentingan diri sendiri sebelum dapat mengusahakan kebahagiaan keluarga subjek, menimbulkan suatu analisis lain dari peneliti. Hal tersebut dapat terjadi karena adanya guilt (rasa bersalah) yang dirasakan subjek terhadap keluarga dan diri sendiri. Guilt muncul ketika seseorang menyangkal untuk memenuhi potensi yang dimiliki, gagal dalam mempersepsikan secara tepat atas kebutuhan orang yang berarti bagi subjek, atau penyangkalan subjek terhadap keterkaitannya dengan alam semesta (Feist \& Feist, 2009). Terdapat tiga macam guilt yang terbentuk, yaitu guilt dengan alam semesta, guilt terhadap orang di sekitar, dan guilt yang muncul terhadap diri sendiri. Pada kasus anak pidana ini, yang terjadi adalah guilt terhadap orang disekitarnya, akibat subjek gagal dalam mempersepsikan kebutuhan keluarga subjek.

Anak pidana yang merasa berhak melanjutkan hidupnya untuk dapat memberikan yang terbaik bagi orang tua merupakan suatu bentuk rasa terima kasih subjek atas segala bentuk pengasuhan yang sudah subjek terima dari para orang tua tersebut, meskipun subjek-subjek ini berada di dalam sebuah lapas anak. Anak-anak pidana ini ingin berbakti, menghormati para orang tua yang sudah merawat mereka dengan menunjukkan keberhasilan setelah menyelesaikan masa pembinaan di dalam lapas anak dengan baik, sehingga anak pidana akan dapat merasa bangga atas dirinya sendiri dan membanggakan orang tua mereka. Pandangan ini merupakan suatu fenomena wajar pada sebagian masyarakat Indonesia. Rasa ingin berterima kasih dan berbakti kepada orang tua yang telah merawat individu ini, dapat terbentuk akibat adanya proses sosialisasi nilai yang dilakukan orang tua selama perkembangan subjek. Proses sosialisasi nilai adalah proses penyaluran nilai sosial dan produk budaya lainnya yang berfungsi sebagai pedoman dalam menghadapi tekanan maupun konflik-konflik sosial (Demirutku, 2007).

\section{Perubahan yang dialami}

Salah satu subjek mengalami perubahan dengan lebih mempertimbangkan konsekuensi atas perbuatan yang akan dilakukan dan tidak hanya memikirkan hal yang dapat diraih pada saat perilaku tersebut terwujud. Perubahan tersebut dapat dipicu akibat adanya pengalaman traumatis bagi individu setelah melakukan perbuatan tersebut, yaitu harus menjalani masa pembinaan di dalam lapas anak dengan segala macam keterbatasannya, sehingga individu memutuskan untuk memperbaiki hidup dengan lebih berhati-hati dalam bertindak. Perubahan ini dapat dijelaskan dengan teori tingkat perkembangan moral yang diungkapkan oleh Kohlberg (dalam Desmita, 2012), bahwa subjek telah berada pada tingkat pasca konvensional, tahap orientasi kontrol sosial-legalistik, dimana pada level ini terdapat semacam perjanjian antara individu dengan lingkungan sosialnya, bahwa suatu perbuatan dinilai baik apabila sesuai dengan perundang-undangan yang berlaku.

Usaha untuk memegang teguh pendirian dengan tetap melakukan tindakan positif dan menghindari tindakan negatif, dilakukan salah satu subjek untuk memperbaiki kesan ayah subjek terhadap subjek yang telah dipermalukan dengan perbuatan melanggar hukum yang dilakukan subjek. Anak pidana lainnya berusaha untuk menahan sikap agresif subjek demi menjaga kepercayaan dan menaati pesan yang disampaikan oleh nenek subjek, dengan tetap melakukan perbuatan positif dan menghindari tindakan-tindakan negatif yang dapat mempermalukan subjek dan keluarga nantinya. Dari kedua temuan yang telah dipaparkan di atas, terdapat hubungan bahwa para subjek memutuskan untuk merubah 
sikap mereka berdasarkan kepercayaan yang diberikan oleh pihak di luar diri subjek, seperti ayah dan nenek subjek. Dalam tingkat perkembangan moral menurut Kohlberg (dalam Desmita, 2012), individu dengan pola pemikiran seperti ini berada dalam tingkat konvensional, dimana suatu perbuatan dinilai baik ketika individu dapat mematuhi harapan dari pihak otoritas atau teman sebaya.

Pada masa remaja, terdapat sebuah konsep yang lebih mendalam tentang Tuhan yang dapat dipahami melalui ajaran agama (Desmita, 2012). Agama dikatakan dapat menstabilkan tingkah laku dan memberikan penjelasan mengapa dan untuk apa seseorang berada di dunia ini. Agama pun dapat memberikan perlindungan rasa aman, terutama bagi remaja yang sedang mencari eksistensi diri (Adams \& Gullotta dalam Desmita, 2012). Hal ini pula yang diyakini oleh para anak pidana, sehingga salah satu anak pidana memilih untuk mendekatkan diri kepada Tuhan dan berdoa sesuai dengan agama yang dianut, dengan harapan subjek diarahkan untuk dapat bersikap lebih baik dan mengurangi sikap agresif yang ditunjukkan subjek selama berada di dalam lapas anak. Subjek lainnya juga selalu melakukan hal yang sama, yaitu berdoa kepada Tuhan untuk mendapatkan ketenangan apabila subjek merasakan stres yang tidak dapat diatasi dengan melakukan kegiatan lain selama di dalam lapas anak.

6. Penerimaan terhadap kehidupan di dalam lapas

Dalam ecological model yang dijelaskan oleh Brofenbrenner (dalam Rice, 2001), menjelaskan mengenai peran lingkungan sosial, salah satunya adalah makrosistem. Yang termasuk dalam makrosistem adalah nilai kepercayaan, nilai moral, adat istiadat, nilai budaya, maupun peraturan hukum yang berlaku di suatu tempat. Brofenbrenner (dalam Rice, 2001) menjelaskan bahwa remaja yang memiliki rentang usia 18-21 tahun, sudah seharusnya menyadari adanya suatu makrosistem dari lingkungannya yang menjadi suatu norma bahkan peraturan dalam menjalani kehidupan sosial. Hal ini telah tercermin dari salah seorang subjek yang telah melakukan penerimaan terhadap kehidupannya di dalam lapas anak sebagai konsekuensi atas pelanggaran hukum yang dilakukan subjek, bahwa seluruh hal yang berhubungan dengan anak pidana telah diatur dalam peraturan perundangundangan. Hal inilah yang membuat subjek memaknai hidupnya di dalam Lembaga Pemasyarakatan Kelas II B Karangasem dengan menerima segala sesuatu yang terjadi dan tetap mengusahakan yang terbaik, tanpa keinginan untuk menuntut lebih dari apa yang menjadi hak subjek selama berada di dalam lapas anak.

Kebermaknaan hidup adalah cara yang digunakan individu untuk menghadapi dunia (Krueger dalam Cahyani, 2011). Hal ini sejalan dengan pendapat Bandura (dalam Rice, 2001) dalam teori social cognitive-nya yang menyatakan bahwa pemaknaan individu terhadap pengaruh lingkungan akan sangat menentukan perilaku yang dilakukan individu nantinya. Hal ini berarti bahwa individu memiliki peran aktif untuk menghadapi hidup yang ditunjukkan dengan cara individu dalam bereaksi terhadap setiap kejadian dalam hidupnya. Cara seperti ini juga diperlihatkan para anak pidana, bahwa dipengaruhi oleh kondisi dan fasilitas yang serba terbatas di dalam lapas, anak pidana memaknai kondisi tersebut dengan menerima, mensyukuri, mengambil manfaat di setiap hal yang terjadi, dan berserah kepada Tuhan, serta berusaha untuk melakukan yang terbaik pada setiap momennya.

Berdasarkan hasil penelitian yang diperoleh, dapat disimpulkan bahwa Kebermaknaan hidup bagi anak pidana yang menjalani masa pembinaan di dalam Lembaga Pemasyarakatan Anak Kelas II B terdiri atas enam aspek, yaitu aspek kepuasan hidup, hal yang paling berarti dalam hidup, kebebasan, kepantasan untuk hidup, perubahan yang dialami, dan penerimaan terhadap kehidupan di dalam lapas.

Terdapat suatu keunikan berdasarkan temuan-temuan yang didapatkan, bahwa kebermaknaan hidup bagi anak pidana di Lembaga Pemasyarakatan Anak Kelas II B Karangasem sangat terkait dengan pengaruh pihak luar, seperti orangtua dan anggota keluarga lainnya, serta rekan sesama anak pidana, meskipun fokus dari penelitian ini adalah kebermaknaan hidup bagi diri anak pidana itu sendiri. Hal tersebut terlihat jelas pada aspek hal yang paling berarti dalam hidup dan aspek kepantasan hidup.

Sebuah penelitian tentunya tidak terlepas dari keterbatasan-keterbatasan, yang seharusnya ditingkatkan agar hasil penelitian ini dapat menjadi lebih baik dan komprehensif. Salah satu dari keterbatasan penelitian ini adalah populasi subjek yang hanya berjenis kelamin laki-laki, sehingga data yang didapatkan menjadi kurang beragam. Hal ini dapat diatasi dengan melakukan penelitian mengenai kebermaknaan hidup selanjutnya dengan populasi anak pidana dengan jenis kelamin perempuan, agar memiliki pembahasan mengenai kebermaknaan hidup yang lebih komprehensif. Keterbatasan lainnya adalah kehadiran petugas lapas anak yang menemani anak pidana dalam proses pengambilan data, yang menyebabkan anak pidana merasa kurang nyaman dalam menyampaikan pendapat yang sebenarnya.

Jauhnya jarak tempuh tempat penelitian juga menjadi keterbatasan bagi penelitian ini, yang berpengaruh terhadap terbatasnya waktu penelitian, sehingga data yang diperoleh belum mencapai titik jenuh (saturated data). Keterbatasan lain dalam penelitian ini, adalah pada saat peneliti melakukan pengambilan data, kegiatan-kegiatan yang dapat merepresentasikan aspek kebermaknaan hidup para anak pidana kurang terlihat, sehingga data yang didapatkan lebih banyak berasal dari hasil wawancara dan diskusi. Untuk mengatasi hal ini, diharapkan kepada peneliti selanjutnya agar lebih teliti dan tekun dalam melakukan pengambilan data. 


\section{A. A. S. S. DEWI DAN D. H. TOBING}

\section{DAFTAR PUSTAKA}

Albertina. (2012). Profil anak pidana (Tidak dipublikasikan). Karangasem: Lembaga pemasyarakatan anak kelas II B karangasem.

Anggono, A. T. (2008). Atribusi sosial narapidana anak di Lembaga Pemasyarakatan Kelas IIA Sragen. Surakarta: Universitas Muhammadiyah Surakarta.

Cahyani, S. T. (2011). The meaning of life people's with diabetes mellitus in adult associate. Depok, Jawa Barat: Gunadarma University.

Demirutku, K. (2007). Parenting styles, internalization of values, and the self concept. Turki: Middle East Technical University.

Departemen Pendidikan Nasional, P. B. (2002). Kamus besar bahasa indonesia. Jakarta: Balai Pustaka.

Desmita. (2012). Psikologi perkembangan. Bandung: PT Remaja Rosdakarya Bandung.

Dewi, S. (2012). Stressor pada anak pidana di Bali-Studi kasus (Tidak dipublikasikan). Denpasar: Universitas udayana.

Feist, J., \& Feist, G. J. (2009). Theories of personality, Seventh edition. New York: McGraw-Hill.

Frankl, V. E. (2004). Mencari makna hidup: Man's search for meaning. Bandung: Penerbit Nuansa.

Ghony, M. D., \& Almanshur, F. (2012). Metodologi penelitian kualitatif. Jogjakarta: Ar-Ruzz Media.

Handayani, T. P. (2010). Kesejahteraan psikologis narapidana remaja di lembaga pemasyarakatan anak kutoarjo. Semarang, Jawa Tengah: Universitas Diponegoro.

Hasinta, F. (2010, Agustus 14). Data profil kriminalitas remaja-Biro pusat statistik. Dipetik Juni 12, 2012, dari Kompasiana.com: http://edukasi.kompasiana.com/ 2010/08/14/kebermaknaanhidup_-225475.html.

Henggaryadi, G. (2008). Hubungan antara body image dengan harga diri pada remaja pria yang mengikuti latihan fitness/kebugaran. Jakarta: Universitas Gunadarma.

Irwansyah, R. (2010, Mei 26). Anak-Citizen journalism. Dipetik Juni 20, 2013, dari Waspada online- Pusat berita dan informasi sumut aceh:

http://www.waspada.co.id/index.php?option=com_content\&vie $\mathrm{w}=$ article\&id=117801:penghuni-lapas-anak-separuh-usiaproduktif $\&$ catid $=14:$ medan $\&$ Itemid $=27$

Lubis, N. L., \& Priyanti, D. (2009, Maret). Makna hidup pada penderita kanker leher rahim. Sumatera Utara, Indonesia.
Matsumoto, D., \& Kupperbusch, C. (2001). Idiocentric and allocentric differences in emotional expression, experience, and the coherence between expression and experience. Asian Journal of Social Psychology , 113-131.

Mazor, \& Enright. (2001). Individuation. Dalam F. P. Rice, The adolescent: Development, relationship, and culture (hal. 28). Boston: A Pearson Education Company.

Moleong, L. J. (2004). Metodologi penelitian kualitatif. Bandung: PT. Remaja Rosdakarya.

Mulyandari, T. R. (2011, Juni 17). Dampak bagi anak pidana yang ditempatkan di Lembaga Pemasyarakatan Kelas I Madiun. Malang: Universitas Brawijaya.

Pujileksono, S. (2009). Masalah-masalah di penjara dalam studi sosial. Surabaya: Universitas Airlangga.

Rice, F. P. (2001). The adolescent: Development, relationship, and culture. Boston: A Pearson Education Company.

Santoso, G. A., \& Royanto, L. R. (2009). Teknik penulisan laporan penelitian kualitatif. Jakarta: LPSP3 UI.

Strauss, A. L. (2003). Qualitative analysis for social scientist. United Kingdom: Cambridge University Press.

Sugiyono. (2012). Metode penelitian kuantitatif, kualitatif dan R \& D. Bandung: Penerbit Alfabeta Bandung.

Suyatno. (2011). Kebermaknaan hidup para lanjut usia. Indonesia: Tidak dipublikasikan.

Taylor, S. E. (2009). Health psychology-Seventh edition. New York: McGraw-Hill.

Teguh. (2013, April 24). Artikel. Dipetik Juni 20, 2013, dari Harian haluan:

http://harianhaluan.com/index.php?option=com_content\&view= article\&id=22879: kenakalan-remajameningkat $\&$ catid $=2$ : sumatera-barat $\&$ Itemid $=71$

Tobing, D. H. (2006). Punk sebagai sebuah jalan hidup/way of life (Sebuah studi eksploratif fenomenologis komunitas punk di Yogyakarta). Yogyakarta: Fakultas Psikologi, Universitas Gadjah Mada (Tidak dipublikasikan).

Yamin, M. (2013, April 29). Metropolis. Dipetik Juni 20, 2013, dari Harian pagi-Padang ekspres: http://padangekspres.co.id/?news=berita\&id=43089

Yan. (2013, April 24). Tentang kami. Dipetik Juni 20, 2013, dari Harian haluan: http://harianhaluan.com/index.php?option=com_content\&view= article\&id=22879:kenakalan-remajameningkat $\&$ catid $=2$ : sumatera-barat $\&$ Itemid $=71$ 